\title{
PEMBERDAYAAN STRATEGI UMKM MELALUI PENGABDIAN KEPADA MASYARAKAT DENGAN PENDEKATAN ANALISIS SWOT
}

\author{
Wahyudin $^{1)}$, Dene Herwanto2), Billy Nugraha3), Hamdani Hamdani ${ }^{4)}$, \\ Candra Galang Gemilang Putra ${ }^{5}$ \\ 1)Program Studi S-1 Teknik Industri, Fakultas Teknik, Universitas Singaperbangsa Karawang, Kabupaten Karawang, \\ Provinsi Jawa Barat, Indonesia \\ Corresponding author: Wahyudin \\ E-mail : hwwahyudin@gmail.com
}

Diterima 25 November 2021, Disetujui 27 November 2021

\begin{abstract}
ABSTRAK
UMKM Farida Snack dan Aphe berupaya menjadi produsen kerupuk kulit yang memiliki nilai lebih di mata konsumenya. Mengingat saat ini masih berlangsungnya ketidakstabilan ekonomi yang disebabkan oleh pandemi covid-19. Sehingga membuat para pelaku UMKM perlu melakukan analisis strategi untuk menjaga produksi yang tetap berjalan. Melalui Pengabdian Kepada Masyarakat ini dengan tujuan untuk pemberdayaan strategi UMKM. Analisis yang dilakukan dengan pendekatan analisis SWOT, dengan lokasi pengabdian kepada masyarakat di Kabupaten Karawang. Hasil dari pengabdian ini adalah diperolehnya analisis SWOT dan rekomendasi yang dapat diimplementasikan. Maka melalui Matriks SWOT yang diperoleh berdasarkan hasil S-O (Strength-Opportunities), W-O (WeaknessesOpportunities), S-T (Strength-Threat) dan W-T (Weaknesses-Threat). Sehingga melalui Matriks SWOT bertujuan untuk mencocokkan peluang dan ancaman sebagai faktor eksternal yang dihadapi perusahaan dengan kekuatan dan kelemahan sebagai internalnya untuk menghasilkan strategi alternatif. Analisis tersebut menggunakan suatu matriks yang terdiri dari 9 sel yang berisikan 4 sel alternatif strategi yang dikatakan sebagai Matriks SWOT.
\end{abstract}

Kata kunci: covid-19 pandemic; SWOT analysis; SWOT matrix.

\begin{abstract}
Farida Snack and Aphe strives to be a producer of skin crackers that have more value in the eyes of consumers. Considering the current economic instability caused by the covid-19 pandemic. So that makes MSMEs need to do strategy analysis to keep production running. Through this Community Service with the aim of empowering MSMEs strategies. The analysis is carried out with a SWOT analysis approach, with the location of community service in Karawang Regency. The result of this devotion is the acquisition of SWOT analysis and recommendations that can be implemented. Thus through the SWOT Matrix obtained based on the results of S-O (Strength-Opportunities), W-O (WeaknessesOpportunities), S-T (Strength-Threat) and W-T (Weaknesses-Threat). Thus through the SWOT Matrix aims to match opportunities and threats as external factors facing the company with strengths and weaknesses as its internal to produce alternative strategies. The analysis uses a matrix consisting of 9 cells containing 4 alternative cell strategies that are said to be swot matrix..
\end{abstract}

Keywords: covid-19 pandemic; SWOT analysis; SWOT matrix.

\section{PENDAHULUAN}

Strategi merupakan akses untuk mencapi tujuan dimasa depan (Thompson, Peteraf, Gamble, \& I, 2013). Proses strategi manajemen dapat menjelaskan tujuan, logis, pendekatan sistematik untuk membuat pilihan utama di dalam organisasi. Manajemen strategi mengatur informasi kualitatif dan kuantitatif di dalam arah membuat keputusan yang efektif di saat organisasi di dalam keraguan (David \& R, 2016). Menurut F. R. David (2006) diversifikasi produk adalah upaya mencari dan mengembangkan produk atau pasar yang baru, atau keduanya dalam rangka mengejar pertumbuhan, peningkatan penjualan, produktivitas, stabilitas dan profitabilitas. Deversifikasi menurut Fandy Tjiptono (2007) dapat dilakukan dengan tiga tahapan: (1) Deversifikasi Konsentrik, produk-produk baru yang diperkenalkan memiliki kaitan atau hubungan dalam hal pemasaran atau teknologi dengan produk yang sudah ada. (2) Deversifikasi Horizontal, perusahaan menambah produk-produk baru yang tidak berkaitan dengan produk yang sudah ada. (3) Diversifikasi Vertikal, produk-produk yang dihasilkan tidak memiliki hubungan dengan pemasaran atau teknologi dengan produk yang 
telah ada (Grundy, 2006). Analisis SWOT di gunakan untuk mengidentifikasi kekuatan dan kelemahan serta peluang dan ancaman yang dimiliki oleh usaha dengan mencari data dari faktor internal dan faktor eksternal perusahaan (Bell \& Rochford, 2016). Kemudian mendaftarkannya ke dalam daftar Evaluasi Faktor Eksternal (EFE) dan Evaluasi Faktor Internal (EFI) (Nofrizal, 2014) Menurut G. C. Tewari (2016) menyebutkan SWOT adalah dari beberapa alat perencanaan strategik yang digunakan oleh bisnis dan organisasi lain untuk memperjelas tujuan dari organisasi untuk mengambarkan pengembangan atau bisnis venture. Setelah analisis SWOT selesai di analisis tahapan selanjutnya membuat General Strategy Matrik. General Strategy Matrik merupakan alat manajemen digunakan untuk membuat strategi alternatif. Menurut $\mathrm{S}$. Muhammad (2008) prinspinya adalah memposisikan SBUSBU ke dalam salah satu dari keempat kuadran yang dibentuk oleh garis horizontal (melukis posisi persaing) dan vertical (mengambarkan tingkat pertumbuhan pasar) (Wheelen, Hunger, \& Hoffman, 2015). Menurut F. R. David (2010) matrik TWOS menyajikan maksud untuk pengembangan strategi berdasarkan kombinasi logika dari faktor-faktor berhubungan dari internal strategi dengan faktor ekstenal dan internal. Thomas L. Wheelen, J. David Hunger dan Alan N. Hoffman (2015) Matriks SOT mengidentifikasi empat faktor konsep, yaitu Strength-Opportunity (S-O), Strength-Thearts (S-T), WeaknessesOpportunity (W-O) and Weaknesses-Thearts (W-T).

Pengertian tentang Usaha Kecil dan Menengah (UKM) atau Small Medium Entreprise Size (SMEs) tidak selalu sama pada setiap negara. Hal ini tergantung konsep yang digunakan, berdasarkan pasal 1 UndangUndang No. 20 Tahun 2008. Definisi UMKM adalah : (1) Usaha mikro adalah usaha produktif milik orang perorangan dan/atau badan usaha perorangan yang memenuhi kriteria usaha mikro sebagaimana diatur dalam undangundang ini. (2) Usaha kecil adalah usaha ekonomi produktif yang berdiri sendiri. Dilakukan oleh perorangan atau badan usaha yang bukan merupakan anak perusahaan atau bukan cabang perusahaan yang dimiliki, dikuasai, atau menjadi bagian baik langsung maupun tidak langsung yang memenuhi kriteria usaha kecil sebagaimana dimaksud dalam undang-undang ini. (3) Usaha menengah adalah usaha ekonomi produktif yang berdiri sendiri. Dilakukan oleh perorangan atau badan usaha yang bukan merupakan anak perusahaan atau cabang perusahaan yang dimiliki, dikuasai, atau menjadi bagian baik langsung maupun tidak langsung sebagaimana dimaksud undang-undang tersebut. Jika dilihat dari besarnya kekayaan bersih dan omzetnya, maka kriteria UMKM menurut Undang-Undang No. 20 Tahun 2008 adalah:

a. Usaha Mikro memiliki aset maksmimal Rp.50 juta dan omzet maksimal Rp.300 juta.

b. Usaha Kecil memiliki aset Rp.50 s/d 500 juta dan omzet Rp.300 juta s/d 2,5 miliar.

c. Usaha Menengah memiliki aset Rp.500 juta s/d 10 miliar dan omzet Rp.2,5 s/d 50 miliar.

d. Kriteria UMKM juga dapat dilihat dari sisi jumlah tenaga kerja. Usaha mikro memiliki tenaga kerja kurang dari 10 orang, usaha kecil memiliki tenaga kerja kurang dari 30 orang, dan usaha menengah memiliki jumlah tenaga kerja maksimal sebanyak 300 orang.

Entreprise upgrading akan berkaitan dengan pertumbuhan perusahaan itu sendiri, dalam hal ini adalah unit-unit produksi dengan skala usaha kecil dan mengengah (UKM) melalui proses inovasi. Beberapa literatur mengungkapkan berbagai konsep dalam menjelaskan hal ini yang berkaitan dengan faktor karakteristik entrepreneur (entrepreneur characteristics), karakteristik perusahaan (firm characteristics), dan jaringan dan lingkungan bisnis perusahaan (inter-firm linkages and the business environment). Dalam kajian ini, kata "upgrading" berkaitan dengan pertumbuhan perusahaan dengan skala Usaha Mikro, Kecil, dan Mengengah (UMKM) yang dihasilkan dari berbagai macam inovasi. Dalam konteks ini, inovasi dapat diartikan sebagai suatu upaya yang berbeda dari perusahaan atau melakukan suatu hal yang sama. Tetapi berbeda dari sisi proses dan metode yang dilakukan oleh kompetitor secara langsung (Schmitz, 1999). Berikut pada Gambar 1. merupakan konsep entreprise upgrading di bawah ini.

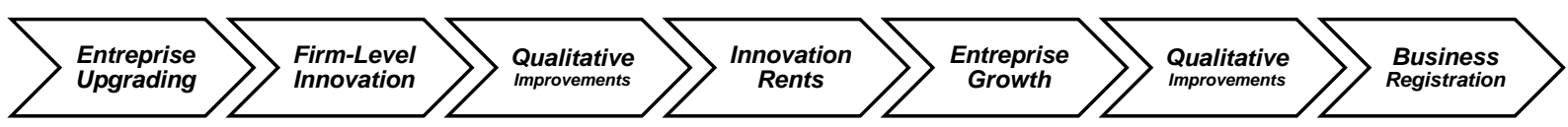

Gambar 1. Konsep Entreprise Upgrading 


\section{METODE}

\section{Kondisi Eksisting}

Desa Sukaluyu, Kecamatan Teluk Jambe Timur dan Desa Adiarsa Barat, Kecamatan Teluk Jambe Barat, Kabupaten Karawang merupakan salah satu daerah yang memanfaatkan limbah hasil pemotongan hewan (kulit sapi). Namun inilah yang belum di tangkap secara maksimal oleh UMKM dan masyarakat sekitar untuk dimanfaaatkan limbah dari pemotongan hewan menjadi produk yang memiliki nilai ekonomi. Seperti produk makanan ringan dan kerajinan berbahan dari kulit sapi. Karena selama ini masyarakat sekitar hanya mengolah kulit sapi dari pemotongan sapi tersebut menjadi kerupuk kulit. Pelaku usaha mikro kecil dan menengah (UMKM) Kerupuk Kulit Farida Snack dan Aphe di Desa Sukaluyu, Kecamatan Teluk Jambe Timur dan Desa Adiarsa Barat, Kecamatan Teluk Jambe Barat, Kabupaten Karawang tidak mengalami pertumbuhan unit usaha setiap tahunya. Selain itu cendrung tetap hal ini dikarenakan masih terbatasnya kemampuan pelaku usaha untuk mendiversifikasikan produk, keterbatasan pengetahuan, keterbatasan bahan baku, keterbatasan relasisasi, dan dana untuk mengembangkan usaha serta perluasaan bisnis. Tujuan dari penelitian ini untuk membantu usaha mikro kecil dan menengah (UMKM) kerupuk kulit dalam menyusun dan merencanakan strategi pengembangan usaha pengelolahan kerupuk kulit. Dengan harapan dapat meningkatkan relasi bisnis, meningkatkan pendapatan, memperluas pangsa pasar dan dapat bersaing dengan produk-produk usaha mikro kecil dan menengah yang ada di Kabupaten Karawang khususnya.

\section{Rangkaian Alur Pengabdian Kepada Masyarakat}

Pengabdian kepada masyarakat ini dilakukan dengan teknik analisis focus and group discussion (FGD) dengan narasumber adalah pemiliki UMKM. Berikut Rangkaian Alur Pengabdian Kepada Masyarakat yang dilakukan:'

a. Melakukan klasifikasi data, faktor-faktor yang menjadi kekuatan dan kelemahan sebagai faktor internal, peluang dan ancaman sebagai faktor eksternal.

b. Membandingkan antara faktor eksternal dengan faktor internal.

c. Menginterpretasikan dan mengembangkan hasil analisis dari bagian $\mathrm{b}$ menjadi keputusan memilih strategi yang memungkinkan untuk dilakukan.

d. Menyusun perencanaan perbaikkan dan/atau peningkatan dari hasil analisis SWOT untuk grooup index.

Sedangkan berikut ini merupakan flowchart dalam melaksanakan kegiatan Pengabdian Kepada Masyarakat, pada Gambar 2. di bawah ini.

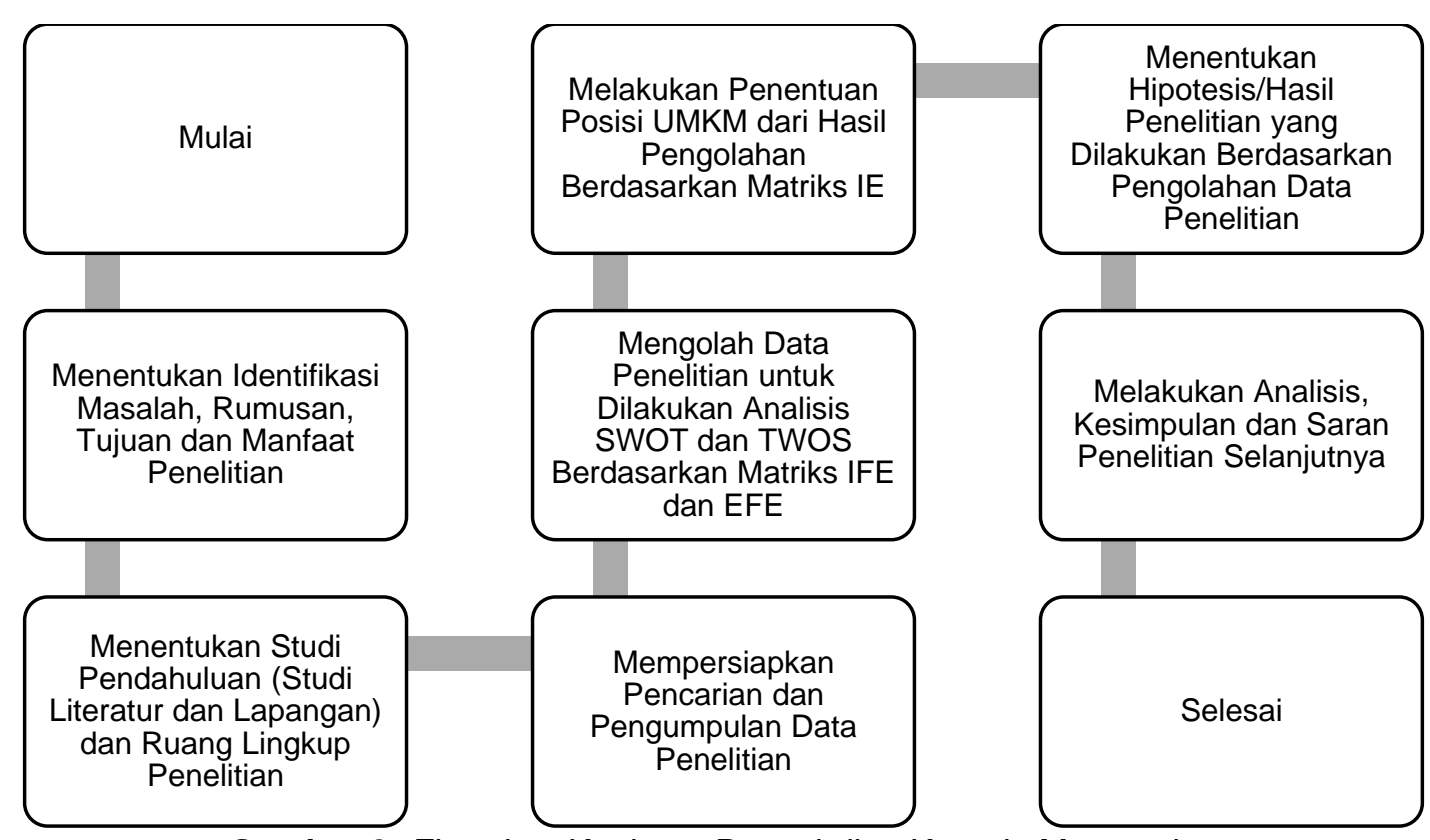

Gambar 2. Flowchart Kegiatan Pengabdian Kepada Masyarakat

\section{HASIL DAN PEMBAHASAN}

\begin{tabular}{lcc}
\multicolumn{1}{c}{ Hasil } & dan & pembahasan pada \\
pengabdian & kepada masyarakat ini \\
menggunakan & Analisis dan Matriks & SWOT
\end{tabular}

untuk menentukan alternatif strategi yang dapat dilakukan dalam memaksimalkan potensi pasar pada UMKM Farida Snack dan Aphe. Adapun tahapan yang dilakukan sebagai berikut. 


\section{Analisis SWOT}

Dalam merumuskan strategi yang dapat dilakukan oleh UMKM dalam memaksimalkan potensi pasar adalah dengan melakukan Analisis SWOT. Analisis ini digunakan untuk mengetahui dan mengidentifikasi potensi yang dimiliki oleh
UMKM. Dari analisis ini akan diketahui seperti kekuatan, kelemahan, peluang, dan juga ancaman. Dari hasil Analisis SWOT ini kemudian dapat dilakukan tindakan lebih lanjut dalam memaksimalkan potensi pasar UMKM. Adapun hasil Analisis SWOT dari UMKM Farida Snack dan Aphe pada Tabel 1. di bawah ini.

Tabel 1. Hasil Analisis SWOT

\begin{tabular}{|c|c|c|c|}
\hline \multicolumn{2}{|r|}{ Strength } & \multicolumn{2}{|r|}{ Weakness } \\
\hline 1 & Memiliki beberapa varian rasa & 1 & Belum memiliki Sosial Media \\
\hline 2 & Terdapat berbagai macam ukuran kemasan & 2 & Bahan baku yang mengambil dari luar \\
\hline 3 & Bahan baku yang berkualitas & 3 & Proses produksi yang masih manual \\
\hline 4 & Telah memiliki izin BPOM, dan MUI & 4 & Tata letak produksi tidak terstruktur \\
\hline 5 & Merk yang telah memiliki perizinan & 5 & Belum ada kerja sama dengan dinas terkait \\
\hline 6 & Adanya jaminan produk dan garansi & 6 & Belum menyentuh warung kecil \\
\hline 7 & Harga yang murah dan tidak terlalu mahal & 7 & $\begin{array}{l}\text { Proses penjualan hanya dilakukan secara } \\
\text { offline }\end{array}$ \\
\hline 8 & Terdapat harga paket yang lebih murah & 8 & Penentuan harga berdasarkan pasaran \\
\hline \multicolumn{2}{|r|}{ Opportunities } & \multicolumn{2}{|r|}{ Threat } \\
\hline 1 & Perkembangan penggunaan Internet & 1 & Adanya pesaing dengan kualitas sama \\
\hline 2 & $\begin{array}{l}\text { Banyaknya jasa influencer sebagai bantuan } \\
\text { iklan }\end{array}$ & 2 & Banyaknya produk subtitusi \\
\hline 3 & Kerupuk sebagai makanan pelengkap & 3 & Bahan baku yang langka \\
\hline 4 & Lokasi produksi yang strategis & 4 & Produk Kadaluarsa \\
\hline 5 & $\begin{array}{l}\text { UMKM yang dinaungi Dinas Koperasi dan } \\
\text { UKM }\end{array}$ & 5 & $\begin{array}{l}\text { Adanya penyanduran merk dengan nama } \\
\text { sama }\end{array}$ \\
\hline 6 & $\begin{array}{l}\text { Masyarakat yang selektif dalam memilih } \\
\text { produk }\end{array}$ & 6 & $\begin{array}{l}\text { Pesaing yang menyisir seluruh segmen } \\
\text { hingga warung kecil }\end{array}$ \\
\hline 7 & Masyarakat yang semakin konsumtif & 7 & $\begin{array}{l}\text { Konsumen yang bosan dengan produk } \\
\text { vang sama }\end{array}$ \\
\hline 8 & Adanya pemberdayaan UMKM dari pemerintah & 8 & Kondisi ekonomi yang sulit \\
\hline
\end{tabular}

\section{Analisis Matriks SWOT}

Analisis ini bertujuan untuk mencocokkan peluang dan ancaman sebagai faktor eksternal yang dihadapi perusahaan dengan kekuatan dan kelemahan internalnya untuk menghasilkan alternatif strategi. Analisis ini menggunakan suatu matriks yang terdiri dari 9 sel yang berisikan 4 sel alternatif strategi yang disebut dengan Matriks SWOT. Berikut ini merupakan hasil matriks SWOT seperti pada Tabel 2. di bawah ini.

Tabel 2. Hasil Matriks SWOT

\begin{tabular}{|c|c|}
\hline \multicolumn{2}{|r|}{$\begin{array}{l}\text { Strength } \\
\text { S-O }\end{array}$} \\
\hline 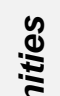 & $\begin{array}{l}\text { Bekerja sama dengan dinas terkait untuk } \\
\text { menjadikan produk sebagai oleh-oleh khas }\end{array}$ \\
\hline$\frac{9}{2}$ & Penetrasi pasar dengan menyisir toko kecil \\
\hline$\delta^{2}$ & $\begin{array}{l}\text { Mengikuti pameran dan bazar yang di adakan } \\
\text { dinas terkait }\end{array}$ \\
\hline \multicolumn{2}{|r|}{ S-T } \\
\hline 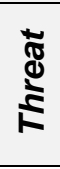 & $\begin{array}{l}\text { Melakukan pengembangan usaha dengan } \\
\text { menambah varian produk } \\
\text { Memproduksi dari bahan baku agar proses } \\
\text { produksi dapat lebih konstan }\end{array}$ \\
\hline
\end{tabular}

Weakness W-O

Merancang alat untuk menjadikan proses produksi yang semi-otomatis

Memaksimalkan pemasaran digital dengan membuat akun sosial media

Melakukan branding dengan menggunakan jasa influencer di sosial media

\section{W-T}

Menata ulang tempat produksi agar pekerjaan lebih tersusun dan terstruktur

Merancang sistem kerja yang baik untuk meningkatkan produktivitas pekerja 
Mengadakan pelatihan pekerja agar kualitas produk dapat terjaga dan meningkatkan produktivitas
Membuat produk dengan kemasan yang lebih ekonomis

\section{Dokumentasi Kegiatan Pengabdian Kepada Masyarakat}

Berikut beberapa bentuk dokumentasi kegiatan pengabdian kepada masyarakat yang telah dilaksanakan, seperti pada Gambar 3. di bawah ini.
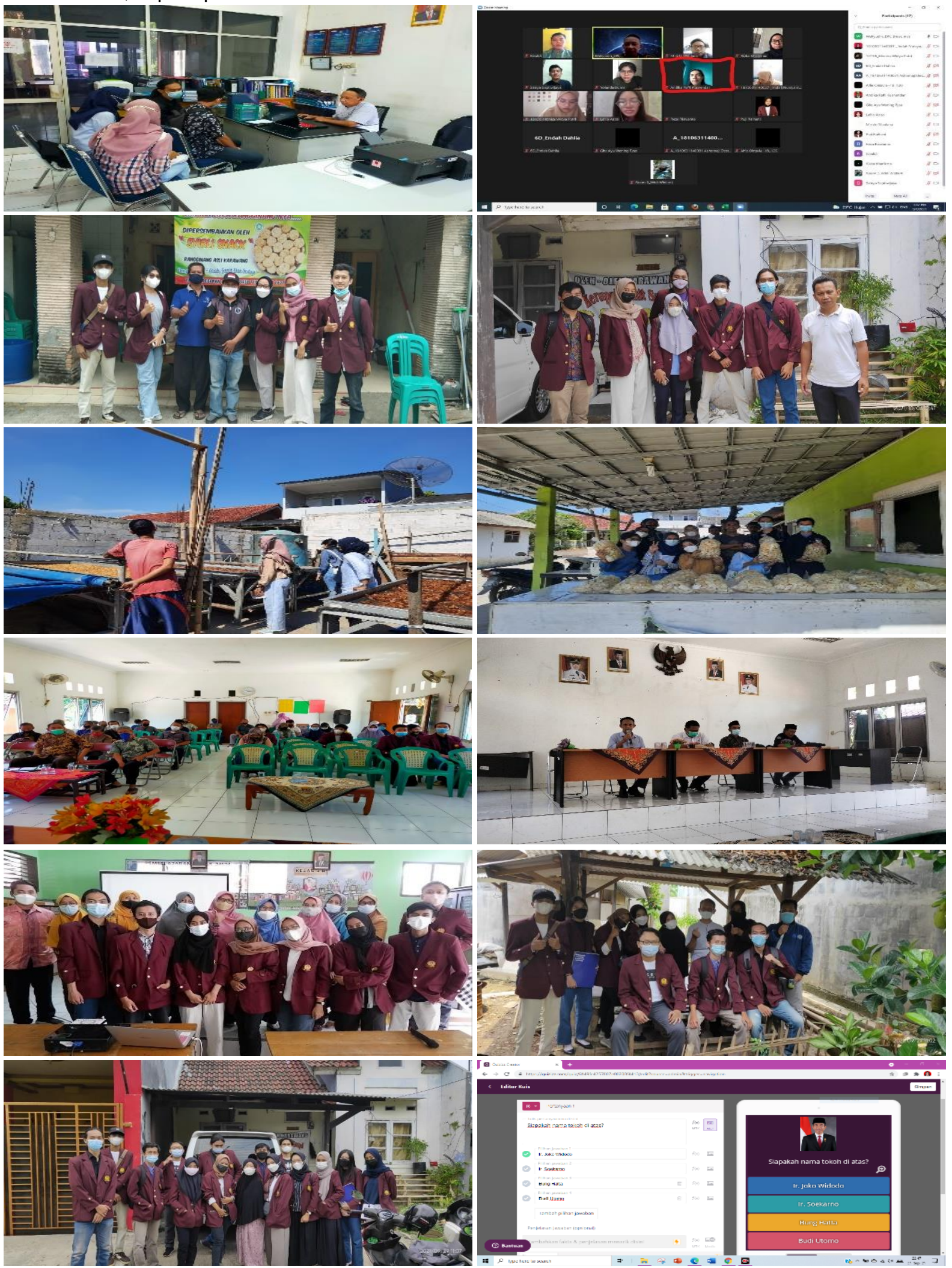

Gambar 3. Dokumentasi Kegiatan Pengabdian Kepada Masyarakat 


\section{SIMPULAN DAN SARAN}

Dalam rangka meningkatkan dan mengembangkan UMKM Farida Snack dan Aphe, maka perlu dilakukannya pemberdayaan strategi UMKM yang tepat di masa pandemi covid-19 sekarang. Tentunya hal ini menjadi tantangan bagi para pelaku UMKM untuk mempertahankan usahanya. Melalui kegiatan pengabdian kepada masyarakat ini dilakukan pemberdayaan strategi UMKM dengan menggunakan pendekatan Analisis SWOT yang dikembangkan dengan Matriks SWOT. Hasil dari pengabdian ini adalah diperolehnya analisis SWOT dan rekomendasi yang dapat diimplementasikan. Maka melalui Matriks SWOT yang diperoleh berdasarkan hasil S-O (Strength-Opportunities), W-O (WeaknessesOpportunities), S-T (Strength-Threat) dan W-T (Weaknesses-Threat). Sehingga melalui Matriks SWOT bertujuan untuk mencocokkan peluang dan ancaman sebagai faktor eksternal yang dihadapi perusahaan dengan kekuatan dan kelemahan sebagai internalnya untuk menghasilkan strategi alternatif. Analisis tersebut menggunakan suatu matriks yang terdiri dari 9 sel yang berisikan 4 sel alternatif strategi yang dikatakan sebagai Matriks SWOT.

\section{UCAPAN TERIMAKASIH}

Ucapan Terimakasih kepada UMKM Farida Snack dan Aphe yang telah mengizinkan untuk dilakukannya Kegiatan Pengabdian Kepada Masyarakat..

\section{DAFTAR RUJUKAN}

Bell, G. G., \& Rochford, L. (2016). Rediscovering SWOT's Integrative Nature: A New Understanding of An Old Framework. International Journal of Management Education, XIV(3), 310326.

David, F. R. (2006). Strategic Management (Penerjemah ed.). Jakarta: Salemba empat.

David, F. R. (2010). Strategic Management (12th ed.). New Jersey: Pearson Education.

David, F. R., \& R, F. (2016). Strategic Management: $A$ Competitive Advantage Approach, Concepts and Cases (15th ed.). England: PearsonPrentice Hall.

Grundy, T. (2006). Rethinking and Reinventing Michael Porter's Five Forces Model. Strategic Change, XV(5), 213-229.

Muhammad, S. (2008). Matriks \& Skenario dalam Strategi (Penerjemah ed.). Yogyakarta: Unit Penerbit dan Percetakan Sekolah Tinggi IImu Manajemen YKPN.
Nofrizal. (2014). Analisis Strategi Bersaing Gudang Digital Yogyakarta dalam Memperluas Pasar. Jurnal IImiah Ekonomi dan Bisnis, XI(2), 481-501.

Schmitz, H. (1999). Growth Constrains on Small Scale Manufacturing in Developing Countries : A Critical Review. World Development, $X(1), 429-450$.

Tewari, G. C. (2016). A SWOT Analysis of Serva Shiksha Abhiyan in Uttar Pradesh. GJRA - Global Journal for Research Analysis, V(9), 255-257.

Thompson, A., Peteraf, M., Gamble, J., \& I, A. J. (2013). Crafting \& Executing Strategy: The Quest for Competitive Advantage: Concepts and Cases (19th ed.). United States of Amerika: McGraw-Hill Education.

Tjiptono, F. (2007). Strategi Pemasaran (8th ed.). Yogyakarta: Andi.

Wheelen, T. L., Hunger, J. D., \& Hoffman, A. N. (2015). Strategic Management abd Business Policy: Globalization, Innovation and Sustainbility (Global Edition ed.). England: Pearson High Education. 